\title{
Effects of a Cognitive Acceleration Program in a Low Socio-Economic High School in Regional Australia
}

\author{
Mary Oliver, Grady Venville \\ Graduate School of Education, University of Western Australia
}

\author{
And \\ Philip Adey \\ Department of Education, Kings College, London
}

\begin{abstract}
This paper presents research on the effects of a cognitive acceleration intervention in science lessons on low socio-economic students in a government high school in regional Western Australia. Thinking Science Australia is a program currently being implemented in Australian junior high school classes. The research was conducted over two years as a case study in one school with students as they entered high school in Year 8 (n $=71$ ). Findings show that significant cognitive gains were made, with concomitant improvement in the state-wide testing in science when participating students were in Year 9, aged 13 and 14. Teachers reported changes to the ways they teach and described the challenges in implementing the intervention program.
\end{abstract}

Key words: Pedagogy, Teacher, Professional Learning, Thinking Skills

\section{Corresponding Author \\ Mary Oliver \\ mary.oliver@uwa.edu.au}

A paper submitted to the International Journal of Science Education, October 2011 


\section{Effects of a Cognitive Acceleration Program in a Low Socio-Economic High School in Regional Australia}

Research on the cognitive development of children has shown that there is a large range of cognitive abilities as students enter high school (Shayer, Küchemann \& Wylam, 1976). Low performing students are often not cognitively 'ready' for the demands of high school science courses, do not enjoy success with the courses available and may leave school with little improvement in their ability to engage with higher cognitive demands. The economic cost of educational performance has been related to cognitive skills as measured by the Programme for International Student Assessment (PISA). Even quite small improvements in cognitive abilities have demonstrated a considerable impact on a country's economy: "an improvement of one-half standard deviation in mathematics and science performance at the individual level implies, by historical experience, an increase in annual growth rates of GDP per capita of $0.87 \% "$ (OECD, 2010, p. 17).

For students in schools in low socioeconomic regions, there may be few local role models of academic success and teachers may be central to fostering academic ambitions for students. Distance from universities, ready access to stimulating experiences and school location contribute to the culture of the school. Children's performance on IQ measures are negatively impacted by low socioeconomic status (SES), childhood stress, and deprivation (Turkheimer, Haley, Waldron, D'Onofrio, \& Gottesman, 2003; Tucker-Drob, Rhemtulla, Harden, Turkheimer, \& Fask, 2010; Hackman, Farah, \& Meaney, 2010). In Australia, the effect of SES on student performance in the 2009 PISA was found to be considerable compared with other countries (Thomson, de Bortoli, Nicholas, Hillman, \& Buckley, 2011). Moreover, low SES students are underrepresented in tertiary education in Australia, despite the efforts of universities and federal government initiatives. Few reports in the literature attest to the ameliorating effects of intervention programs in increasing low SES students' representation at the tertiary level.

Anecdotally, generations have become taller, fitter and more intelligent. Increasing use of technology, ready availability and ease of access of information are thought to have led to today's children being more intelligent. The Flynn effect has been suggested to account for the general worldwide improvement in performance in intelligence tests (Baxendale, 2010). Flynn proposed that the increase in abstract thinking and manipulation of abstract concepts accounted for such a phenomenon. Factors such as improved nutrition, school attendance, maternal health and treatment of infection are all likely to have an impacted on measured intelligence (Eppig, Fincher, \& Thornhill, 2010). This suggests that school populations might also show an increase in scores of measured intelligence over time. Recent reports have shown that far from improving, the mean performance of 11 to 12 year old students in the UK has deteriorated over 30 years (Shayer, Ginsburg \& Coe, 2007; Shayer \& Ginsburg, 2009). The large number of students tested suggests that these are not spurious findings and very much call into questions the Flynn effect.

Published commercially as Thinking Science (Adey, Shayer_\& Yates, 1990), the Cognitive Acceleration through Science Education (CASE) program was developed at King's College, London, UK. Considerable evidence has been published on the effects of the CASE strategies on children's cognitive development and school 
achievement with summaries found in Adey and Shayer (2002) and Shayer (1999). The findings have demonstrated the potential for raising high school students' achievement in science, with evidence of long-term, far-transfer effects and high validity and reliability measures (Shayer et al., 1981). Three years after the intervention, students in CASE schools achieved higher results than peers in control schools in the British General Certificate of Secondary Education (GCSE), the examination taken when they are 16 years of age. The average gain for the GCSEs reported for students in CASE schools was 1.05 grades (0.6 standard deviations) in science, 0.95 grades ( 0.5 standard deviations) in mathematics, and 0.90 grades $(0.57$ standard deviations) in English Language (Adey \& Shayer, 2002). Improved student achievement in subjects other than science has been attributed to CASE having an effect on general intellectual growth, as well as on science-related thinking skills (Adey \& Shayer, 1994). The achievement gains were found for the full ability range of pre-intervention students. Independent reviews have supported these findings (e.g. McGuinness, 1999; Higgins et al. 2005). A report from Ofsted (the UK Office for Standards in Education, Children's Services and Skills) that outlined the strengths and weaknesses of science in schools, highlighted the CASE program, the positive impact it has on the science achievement of students and professional development of science teachers (Ofsted, 2008).

Once the early CASE research had been completed, the theoretical and practical approach was applied to other disciplines, including mathematics and technology, as well as programs for younger children in the early childhood and middle primary years (Shayer \& Adey, 2002; Adey, Robertson \& Venville, 2003). Cognitive acceleration programs also have been successfully adapted and trialled in other places in the world including Oregon (USA) (Endler \& Bond, 2008), China (Lin et al., 2003), Malawi (Mbano, 2003), Finland (Hautamäki et al., 2002) and Pakistan (Iqbal \& Shayer, 2000).

\section{Purpose and Research Questions}

The purpose of this research was to determine the effect on high school students and their teachers of implementing the Cognitive Acceleration through Science Education (CASE) program in a low socio-economic high school in regional Australia. Effects were determined by measuring cognitive gains made over two years, and students' performance on state wide and national testing in science, mathematics and literacy.

More specifically, the research questions addressed in the research reported in this paper were:

1. What were the effects of the cognitive acceleration program on the case study students' cognitive development?

2. What were the effects of the cognitive acceleration program on the case study students' achievement in science, mathematics and English?

3. What were the students' and teachers' perceptions of participation in the cognitive acceleration program?

The Thinking Science Australia research project aims to directly address a significant national problem in Australia of both falling achievement in and attitudes towards science. Year 8 science scores in the Trends in Mathematics and Science Study 
(TIMSS: conducted by the International Association for the Evaluation of Educational Achievement, IEA) have declined significantly over the cycles of TIMSS since 1995 (Thompson et al., 2008). In the 2007 cycle of testing, Australia's average science score at Year 8 showed a statistically significant decrease of 12 score points from that of TIMSS 2003. The results also show that eight per cent of Australian Year 8 students did not reach the minimum standards in science as defined by the international benchmarks (Thompson et al., 2008). These factors, combined with significant improvements by other countries, have moved Australia down in the rankings. Asian countries (Singapore, Chinese Taipei, Korea, Hong Kong and Japan) outperformed Australia as did England, Czech Republic and Hungary. In 2007, the Russian Federation and Slovenia also significantly outperformed Australia (Thompson, 2008). The evidence suggested that the improvement of already high scores by some countries was often associated with systemic curricular reform (Thompson et al., 2008).

The Longitudinal Surveys of Australian Youth (Fullarton et al., 2003), and more recently, Ainley et al. (2008), confirmed declining national enrolments in science and that Australia faces significant challenges in boosting participation in science in school education, university studies and in the teaching workforce. Whereas SES is the most highly correlated variable associated with literacy scores in PISA, it seems that activities students undertake outside of school explains the variance within scores for engagement in science (Woods-McConny et al., in press).

Australian Year 8 students generally have highly qualified teachers, have relatively high levels of educational resources in the home including computer and internet connection, and a majority of Australian students attend schools where principals report a high positive school climate (Thompson et al., 2008). The declining trends flout the general educational environment and are indicative of a crisis that has already been foreshadowed (Tytler, 2007). Clearly, new and innovative approaches that have the potential to contribute to an improvement in Australian high school students' science achievement are needed.

As a consequence of the recent TIMMS results in Year 8 science, the Australian Council of Educational Research recommend that, "greater attention be given to curriculum and teaching in junior secondary science" and that a "failure to give sufficient attention to science in the junior secondary years is likely to have consequences for building the basis for education in the science-based occupations and for building a scientifically literate community" (Thompson et al., 2008a p. x). Australia is currently at the beginning of major curriculum reform and over the next decade, we have a unique opportunity to make major changes and developments in the way that school science is viewed and implemented in schools. The CASE, or Thinking Science, program complements the Australian national science curriculum.

The new Australian national science curriculum states: "critical and creative thinking are embedded in a range of skills taught in science, including the ability to pose questions, make predictions, speculate, solve problems through investigation, make evidence-based decisions, analyse and evaluate evidence and summarise information" (Australian Curriculum, Assessment and Reporting Authority [ACARA], available online, 2011). The federal government has also identified teacher quality as a significant determinant of educational success having a measurable impact on student 
outcomes (DEEWR, 2011). For teachers, however, it is not always clear what is included in the hierarchy of thinking skills, how they can be delivered and evaluated or even how they impact students' learning.

\section{Background and Theoretical Framework}

\section{Cognitive acceleration, thinking skills and curriculum}

Thinking Science Australia program is based on the hypothesis that there is some general intellectual function in children, which develops with age, and is influenced both by the environment and by maturation (Adey \& Shayer, 2002). Drawing on the developmental psychology of Piaget (see Shayer, 2002) and the socio-cultural psychology of Vygotsky (see Moll, 1990) six principles underpin the theoretical framework: 1. schema theory, 2. concrete preparation, 3. cognitive conflict, 4. social construction, 5. metacognition, and 6. bridging (see Shayer, 2003 for elaboration). In addition to the contributions made by genetics and maturation (and apparently at different ages (Davis, Haworth, \& Plomin, 2009), cognitive stimulation of students in schools rests a priori with the teacher through both the curriculum delivered and the pedagogy utilised.

Reasoning patterns (or schemata) specifically addressed through the CASE activities include: controlling variables, ratio and proportionality, compensation and equilibrium to analyse process, using correlation, probability, determining criteria for classification, using formal models of thinking and understanding compound variables. Lessons spiral through increasing levels of complexity of these reasoning patterns. Concrete preparation involves the teacher establishing a problem for the students to consider, negotiating any associated ideas and terminology needed to understand the problem. Cognitive conflict draws on the Piagetian idea of equilibration and the Vygotskian idea of a zone of proximal development (ZPD). Both these notions lead us to suppose that cognition is stimulated by the presentation of intellectual challenges of moderate difficulty that must be accompanied by support (or scaffolding) to discuss, question, suggest and problem solve. Students are encouraged to consider a range of possible explanations for the problem. Social construction is the shared development of explanations of and understandings about the problem and potential solutions.

Teachers play a critical role in establishing the problem to be solved and then asking probing questions of students but not offering solutions. Active participation by all students is required, as all are expected to negotiate explanations and solve problems. These processes resonate well with the current interest by educators in pedagogy: group work, problem-solving and challenging teaching. Metacognition, involves students reflecting on their thinking and articulating their approaches taken to problem solving thus enabling other students to access other ways of thinking and evaluating. Finally, bridging, involves applying the ideas developed to other problems in the real world. Associated science lessons can be used to help reinforce and remind students about the range of problem-solving strategies and ways of thinking they developed during these thinking lessons.

\section{Research Design and Methods}


The research was an exploratory case study (Yin, 1989) conducted in one regional high school. The exploratory nature of this research arises from the use of the data from the one school as a pilot study prior to the professional learning program being implemented in other schools in Australia. We report on this one case study, in which all students participated in the intervention over two years when they were in Year 8 and Year 9 (12 to 14 years old). The case study included the collection of both quantitative and qualitative data including tests of cognitive development; literacy, numeracy and science achievement data; teacher interviews; student surveys; and, classroom observations. The classroom observation data are not included in this paper.

A crucial aspect of this mixed methods case study was to integrate the two sets of inferences that were generated by the quantitative and qualitative data sets (Tashakkori \& Teddlie, 2008). This process resulted in meta-inferences about the entire data set with regard to the research questions and has enhanced the rigour of the research. Moreover, the mixed method approach is expected to take the findings beyond those that could be generated by one method alone (Cresswell, 2009).

The case study school is located about $100 \mathrm{~km}$ south of the Western Australian state capital central business district. It is a government, co-educational school with enrolments from outlying towns and farming communities. The catchment area of the school lies in a region of falling socio economic status and this is reflected in the Index of Community Socio-Educational Advantage (ICSEA) developed by the Australian Curriculum, Assessment and Reporting Authority (ACARA). Variables used to determine the ICSEA are derived from the Australian Bureau of Statistics (ABS) and include parental occupation and education level, location of the school (rural, regional metropolitan), proportion of students with languages other than English, proportion of Indigenous students. The average ICSEA value is 1000 and the distribution of students according to parental income is given on the MySchools website (www.myschool.edu.au). The case study school has an ICSEA of 947 with the distribution of parental income heavily skewed towards the bottom half, with 57\% in the lowest quartile. This population of between 550-700 students from Years 8-12 is considered to be typically unrepresented in mainstream tertiary education with $8 \%$ of students from the 2010 graduating cohort going on to university. School priorities include improving attendance, literacy, engaging students, and using ICT. The school also has Football Academy that provides engagement and the opportunity for about 40 boys who are included in each year cohort in their own class.

\section{The professional development program}

Over the course of two years, the six case study science teachers participated in six days of professional learning away from school. The implementation was supported by the school administration, laboratory technicians and all science teachers. In the first, two-day workshop, teachers were introduced to the teaching materials, activities and the theoretical underpinnings of the program. Experienced teachers modelled lessons during the workshop, and these were then 'unpacked' to identify the different principles.

The model of professional development (PD), or professional learning, was adapted from Adey, Hewitt, Hewitt \& Landau (2004). The seven days of PD extends over the 
course of two years with teachers participating in two full days introduction to the program prior to the first year of implementation. Figure 1 provides an overview of the PD program.

Insert Figure 1 about here

All PD workshops were structured to enable teachers to construct their own understanding of the theoretical principles of cognitive acceleration, modelling the types of activities, organisation and delivery of the materials. All participating teachers practised teaching one of the lessons in front of their peers, gave each other feedback, planned for implementation and collaboratively developed questions appropriate for different activities. Each subsequent workshop began with a session which enabled teachers to share their experiences of the intervention program and then progressed to reflection on the progress of the lessons and any changes to their teaching.

\section{Determining the cognitive level of students}

The Science Reasoning Tasks (SRT) were used to determine students level of cognitive development before and after the intervention of Thinking Science. SRT tests are a well documented, validated measure to gauge the cognitive level of students (Shayer, Adey, \& Wylam, 1981). The SRT (volume and heaviness) was administered to all Year 8 students prior to the implementation of Thinking Science program and a different SRT (equilibrium and balance) on completion of the lessons at the end of the second year. The test was administered by teachers in their science classes and the test papers were scored by researchers and cross checked for reliability.

All students $(n=120)$ at the beginning of Year 8 were tested and all students at the completion of Year $9(n=116)$ were tested. Of these, the twice tested students numbered 68. Data from these students were compiled to determine cognitive gains using a rating scaling Rasch analysis. Published data with control and experimental groups have been available for researchers to use for comparative purposes, particularly in the absence of particular populations. We drew on this data (Adey \& Shayer, 1990) to gauge the effect of the intervention with the population from the case study school described here. We might expect to see that a measure of reasoning, the Piagetian Science Reasoning Tasks (SRT) to be replicated with similar results in similar age-matched though temporally (and spatially) disparate school populations.

Effect sizes quantify the differences between two or more groups. An effect size is the difference in means of two groups or of one group pre and post-intervention, divided by the pooled standard deviation of the groups. Cohen's description of effect sizes clarifies what this means in concrete terms: for example, the 'difference in IQ between PhD holders and typical college freshmen ... is about $0.8^{\prime}$ ' (Coe, 2002, p. 3), as is the difference in height between 13 and 18 year old females. Difference in spelling age between 11 and 12 year olds was determined to be 0.3 . Effect sizes of 0.2 are considered to be small, 0.5 medium and 0.8 large, with 0.4 being regarded as the level at which "the effects of the innovation enhance achievement in such a way that we can notice" (Hattie, 1999, p. 17). Hattie recently suggested that an effect size of 1.0 equates to "advancing children's learning by two to three years" (Hattie, 2009, p. 7). 


\section{Determining the achievement in science, numeracy and literacy}

The National Assessment Program-Literacy and Numeracy (NAPLAN) tests and the state-wide Western Australian Monitoring Standards in Education (WAMSE) were used as measures of achievement. NAPLAN is a literacy and numeracy assessment of all students in all Australian states and territories administered annually in Years 3, 5, 7 and 9. The literacy component examines reading writing and language conventions. The numeracy includes items on number; algebra, function and pattern; space; and, measurement, chance and data (http://det.wa.edu.au/educationalmeasurement/detcms/portal/). The WAMSE assessment program tests students' knowledge, skills and conceptual understanding in Science and Society and Environment and is designed to complement the information from the national NAPLAN testing program. The science component of the WAMSE was used for this study. The WAMSE science tests are based on the Western Australian Curriculum Framework and tests students' understanding of investigating in the context of four conceptual outcomes including life and living, energy and change, Earth and beyond and natural and processed materials. http://det.wa.edu.au/educationalmeasurement/detcms/portal/ )

Results are statistically equated to the existing WAMSE scale, which allows the comparison of performance of different year levels and the same students over time. WAMSE is administered annually in Year 5, 7 and 9 and provides schools with student and school level information.

The data used in this case study were provided through the Department of Education in Western Australia which houses all the data for state-wide, national and international assessments for students in Western Australia. Gain scores between the Year 7 and Year 9 tests in literacy, numeracy and science were calculated for each twice tested student and compared with the cohort of twice tested students in Western Australia. Students in this case study were assessed on the state-wide and national tests mid way through Year 7 and Year 9. It is important to note that the Year 9 tests were conducted about four months prior to the completion of the Thinking Science program in Year 9.

\section{Interviews}

At several points during the two years, the participating science teachers were interviewed about the Thinking Science lessons and the professional learning program. These interviews were recorded and transcribed. The shared experiences of teachers talking about and reflecting upon specific teaching was central to the research. Further, teachers' written comments on the intervention were gathered at the workshops. Teachers were asked to comment on how their own practice had changed, how students engaged with the lessons, and whether they had noticed any impact on other science lessons. Specifically, teachers were asked about the support for implementing the intervention, what was positive / frustrating in implementing the intervention, what had changed about their teaching, and the ease of 'bridging' to other science lessons. Transcripts of teacher interviews from this case study were scrutinised and excerpts that both supported and questioned the program of professional learning were isolated and several representative quotations were selected to include in this paper.

\section{Students' questionnaire}


A questionnaire was used to collect data from participating students about their perspectives of the Thinking Science lessons at the end of each of the two years of the program. We asked students for their comments about the intervention: did they enjoy the lessons? What was positive about the lessons? What was the most difficult / easiest part? How did they feel? Did these lessons help? Student responses to each question were classified as 'positive,' 'negative' and 'neutral' and the number of responses in each category tallied. Representative examples of each type of response were selected to include as examples in the results section of this paper.

\section{Results}

\section{Effects on cognitive development}

Table 1 presents the data of cognitive gains from students in the case study school and the control sample as reported by Adey and Shayer (1990). A total of 68 students were twice tested from the initial school sample of 116 . The case study students started at a lower mean cognitive level than the control population, but made greater cognitive gains over the intervention period.

Insert Table 1 about here

The effect size of 0.47 compares with the gain made by the control group. For this cohort of students certainly falls within what Hattie described as being of education merit. The intervention of the Thinking Science lessons had a differential impact on male and female students. Data from the case study school suggest a greater beneficial impact on the male students with a larger effect size being on the all male football specialist students. Table 2 shows the cognitive gains with the all male football specialist students showing greatest gains from this cohort.

Insert Table 2 about here

The all male football specialist student comprised a small number of students who were grouped with other male students from other year groups at the start of Year 9 as part of a sporting academy. These students were taught as a particular group with students for all mainstream school subjects except for the Thinking Science lesson once a fortnight. Female students showed greater gains than the control female population, though lower gains than their male peers at the case study school.

\section{Effects on students' achievement in science, numeracy and literacy}

Data from both the national National Assessment Program-Literacy and Numeracy

(NAPLAN) and the state-wide, Western Australian Monitoring Standards in Education (WAMSE) were used to determine achievement gains between Years 7 and 9 for the case study students. These gains were compared with reported gains from the Department of Education for students in Western Australia for whom 'matched' (twice tested students) data exists in Years 7 and 9.

Insert Table 3 about here 
Based on these data, it is evident that a reduction in teaching time for the science curriculum to enable the Thinking Science program to be implemented, did not have a detrimental impact on students' achievement in the state-wide science test midway through Year 9. Other test results show gains close to the state mean gain in reading, spelling and numeracy.

For the all male football specialist students, the mean gain made in science was nearly double the state average. The same cannot be said for the reading or spelling test, where the gains were slightly below the state average. Gains in numeracy were greater than the school cohort and state. The all male football specialist students gained more in both science and mathematics as measured by WAMSE and NAPLAN tests than their peers. As a cohort, these students have made 'better than expected' progress in science compared with their other [tested] subjects than their state wide peers in government schools.

\section{Teachers' perceptions}

All science teachers at the case school attended the professional learning workshops throughout the two-year period. One young teacher took on the responsibility of organizing and setting up the lessons, creating a timetable for his peers to teach the Thinking Science lessons, trying them out in his class and talking through the lessons with his colleagues. The other teachers in the department were not all so enthusiastic about the program, some having many years of teaching experience. The school administration made determined efforts to improve student performance and was instrumental in ensuring compliance with the teaching, attendance at and participation in the professional learning workshops.

All teachers spoke of the involvement and support of the school Principal. The intervention program became part of the school plan, so there is a sense of accountability of teacher performance and explicit support for the efforts of the teacher in charge of the intervention program.

When reflecting on the lessons, one teacher spoke of:

The thing I like about it is they construct their own ideas rather than me telling them about it. They have to learn it themselves and they have to come up with it themselves. With the pipes, they really get the variables and that you can only change one. Once they've got that, it's really easy to reinforce it.

I made the demo a bit of an interactive thing, which I think they liked. They don't expect it to be so different.

When asked about what had been positive, teachers identified improved student outcomes, enjoyment of the students, the stand-alone nature of the lessons, and the requirement for students to do all the thinking. They commented on the way on which students facing the cognitive conflict are motivated to think. The ease with which teachers were able to bridge to other lessons in the normal science classes helps to reinforce the schema in the minds of students and seems to have been easier for some than others. One of the teachers included some strategies to increase accountability of students, for example, a reminder to students of the two demands in these sorts of thinking lessons: participation and thinking. 
The frustrations in implementing the program were both intrinsic (instructions difficult to follow, hard to read, hard work) and extrinsic such as organising rooming, materials, timetabling. Teachers commented that:

Some of the teachers don't appreciate change.

I find the lessons at times hard to follow so haven't embraced it as much as I'd like.

I think it's not suitable for teachers to do in their first year of teaching because you need to have very good control of your class in behaviour management.

One teacher commented on the pedagogical changes, which he identified as being helpful in his and other classes. The teachers exhibited a range of attitudes and commitment to the implementation of the Thinking Science program, from the highly sceptical and unwilling to advocate and lead authority for teachers in other schools.

\section{Students' perceptions}

The questionnaire was administered to all students at the end of Years 8 and 9 and completed anonymously by all students. Table 4 provides information about the percentage of positive, neutral and negative comments that were provided as responses to each question in the students' questionnaire.

Insert table 4 about here

Among the students written responses were the following positive comments:

I think that it is good that we do them because it means we are not just working on other things in science we are also thinking about them when we are doing thinking science.

I've learnt new things and I look at things differently afterwards.

I have done a lot more thinking about the data I have collected.

Now when we do an investigation, I look at the questions with a different attitude/state of mind.

A minority of students had different views:

Kind of I don't know, some were really boring and some were fun.

No they just didn't interest me.

Ifelt the same as if it was a normal lesson.

When asked about which part of the lessons was most difficult, $58 \%$ students responded that the 'thinking' part and many articulated this clearly: 
I think the second part is the most difficult because we have to think about it and answer some questions.

The end part where we got asked questions about how we got our answers.

The 'thinking' part of the lessons where students work in small groups is indeed challenging for students.

\section{Discussion}

Results from the intervention program within this case study show positive effects in students' levels of thinking and science achievement compared with students from similar schools. The effect size enables a comparison to be made between the two different school populations and is comparable with the published data (Adey \& Shayer, 1990). The Piagetian Reasoning Tasks indicated that students in the case study school made considerable cognitive gains over the two-year period. However, their final mean baseline level was still much lower compared with the control cohort. The control data, although temporally and spatially dislocated, provide us with a way of determining whether the intervention program in the case study school was effective. Additionally, the data suggest that boys of this age group (in Years 8-9) were more positively impacted by the intervention than girls.

The impact of the intervention on the state-wide science tests in Year 9 is of interest, particularly considering that the class time devoted to 'normal' science curricular activities was reduced over the two year period to allow for the implementation of this intervention program. This leads us to suggest that the students' general ability has been improved as a result of the intervention program as they have demonstrated cognitive gains, and compared with similar schools, greater improvements in the state-wide tests in science. The national testing program of literacy and numeracy also confirmed that the students improved compared with 'similar' schools. It remains to be seen whether the cognitive gains made by this cohort of students will be translated into improved scholastic performance in their later school years and this will be the subject of further research.

School administrative support for the intervention was central to the implementation. The school principal attended and supported the teachers' participation in the workshops during the professional learning days. Schools cannot mandate teacher collaboration, but they can enable and encourage teachers to be brought together with a common purpose. We speculate that the collaborative style of the professional learning models the pedagogy for teachers and supports teachers' efforts to take on this sort of intervention (Adey et al., 2004, p. 166; Shayer \& Adhami, 2010). In line with the federal government's aim to improve teacher quality, the school principal's overt support for and participation in the workshops affirms the value of the professional learning and the place of the intervention in promoting student learning at the school. Such positive results have only been brought about by sustained commitment by school administrators and, in particular, one teacher's commitment to improving the educational outcomes of all the students. 
It is tantalising to speculate on the effect an intervention program may have in mitigating the educational disadvantage of low SES. Educational interventions such as Thinking Science may well assist in raising the aspirations of students as well as the cognitive abilities of students currently under represented in science at tertiary education.

Given the findings of this case study, it is pertinent to consider how such improvements in children's thinking are brought about? The activities developed give rise to classroom work focused directly within the different schema. The cognitive conflict, the 'something that doesn't quite make sense' drives the conversation and problem solving of the students working together throughout the lesson as they engage with the different challenges. Collaborative or purposeful group work is thus the vehicle of the "jumps in children's cognitive development ... made when they witness a successful performance in a child like themselves and towards which they may have contributed" (Shayer \& Adhami, 2010, p. 379). The role of the teacher as facilitator, not the arbiter of children's thinking, is demanding: they reflect back to students the ideas that emerge, perhaps suggest alternatives, question whether there are 'other ways of looking' at the data. Teachers' use of Socratic questions can be developed and encouraged through the professional learning, in classroom peer support and feedback. Teachers do not provide answers or solutions but encourage students to explore together possible solutions. That this is so powerful is surprising: undergraduate students in a group showed an improvement in their understanding as a result of peer discussion, "even when none in the discussion group originally [knew] the answer" (Smith, Wood, Adams, Wieman, Knight, Guild, \& Su, 2009, p. 122). For students accessing the way of thinking by hearing another peer articulate the way of solving a particular problem may enable him or her to use that way of thinking in another situation, developing both skills in explaining and metacognition. There are thus sustained periods where teachers foster uncertainty in students and this may well be impacting on students' self efficacy.

The role of implicit theories of intelligence suggests that when students have the belief that their intelligence is malleable, this augurs well for a positive increase in their school performance (Blackwell, Trzesniewski \& Dweck, 2007). Students reflecting on their Thinking Science intervention lessons included comments that certainly suggest their surprise at their thinking (e.g. I didn't know I could think in that way). It may be that these students have become more confident working with periods of uncertainty, better listeners and more capable of internalising the concepts articulated in lessons. These factors need to be investigated further in order to fully understand the impact of Thinking Science program on the students.

Implementation of the intervention was not seamless: quite apart from building refurbishment, teacher preparation was not always ideal. Unwilling and/or transient teachers did not always commit to the intervention and delivering these lessons in a way that promotes thinking was too challenging for some. Nevertheless, the data warrants scaling up the research with a number of possible research areas to consider such as the nature of teacher change, the role of administration in supporting educational interventions, promoting collegiality and trust in departments and determining the role of implicit theories in student cognitive gain. 
Replication of these findings on a larger scale will have policy implications. The costbenefit analysis of professional development reported by Shymansky (2011) suggests that sustained teacher professional development impacts students' learning outcomes (Shymansky, Wang, Annetta, Yore \& Everett, 2011). Teacher quality impacts on student achievement (Taylor, Roehrig, Hensler, Connor, \& Schatschneider, 2010) and improving teacher quality is one of the Australian federal government's priorities so findings from our research will need to be communicated with this audience. A cautionary approach suggests that whilst a "causal interpretation is ...plausible [this] should not excuse any lowering of our critical standards" (Coe, 2009, p. 373). A cohort of students from a low achieving school may not all transform into high achieving students, but the cognitive gains made in this case study suggest that more possibilities will be open to them. These data encourage us to pursue a larger scale research program with students from a greater range of schools.

\section{References}

Adey, P., G. Hewitt, G., Hewitt, J., \& Landau, N. (2004). The professional development of teachers: Practice and theory. Dordrecht, The Netherlands: Kluwer Academic Publishers.

Adey, P., \& Shayer, M. (1990). Accelerating the development of formal thinking in middle and high school students. Journal of Research in Science Teaching, 27(3), 267-285.

Adey, P. \& Shayer, M. (1994). Really raising standards: Cognitive intervention and academic achievement. London: Routledge.

Adey, P., Shayer, M., \& Yates, C. (1995). Thinking Science: Student and teachers' materials for the CASE intervention ( $2^{\text {nd }}$ edn). London: Nelson. $3^{\text {rd }}$ edn. Published 2001, Nelson Thornes.

Adey, P., \& Shayer, M. (2002). Cognitive acceleration comes of age. In M. Shayer \& P. Adey (Eds.), Learning intelligence (pp. 1-17). Buckingham, UK: Open University Press.

Adey, P., Robertson, A., \& Venville, G. (2002). Effects of a cognitive acceleration programme on Year 1 pupils. British Journal of Educational Psychology, 72, 125.

Ainley, J., Kos, J., \& Nicholas, M. (2008). Participation in science, mathematics and technology in Australian education. ACER Research Monograph No 63.

Camberwell, Victoria: Australian Council for Educational Research. Accessed 20 March 2011 at: http://www.acer.edu.au/research_reports/monographs.html.

Australian Curriculum, The (2011) Australian Curriculum, Assessment and Reporting Authority (ACARA) accessed 20 March 2011 at http://www.australiancurriculum.edu.au.

Baxendale, S. (2010). The Flynn effect and memory function. Journal of Clinical and Experimental Neuropsychology, 32(7), 699-703.

Blackwell, L. S., Trzesniewski, K. H., \& Dweck, C. S. (2007). Implicit theories of intelligence predict achievement across an adolescent transition: A longitudinal study and an intervention. Child Development, 78: 246-263.

Coe, R. (2009). It's the effect size, stupid. What effect size is and why it is important. Paper presented Annual Conference of the British Educational Research Association, University of Exeter, England, 12-14 September 2002.

Coe, R. (2002). School improvement: Reality and illusion. British Journal of Educational Studies, 57(4), 363-379. 
Cresswell, J. W. (2009). Research design: Qualitative, quantitative, and mixed methods approaches. Thousand Oaks, CA: Sage.

Davis, O. S. P., Haworth, C. M. A., \& Plomin, R. (2009). Dramatic increase in heritability of cognitive development from early to middle childhood: An 8year longitudinal study of 8700 pairs of twins. Psychological Science, 10, 1301-1308.

Department of Education, Employment and Workplace Relations (DEEWR). (2011). Quality teaching. Accessed March 182011 http://www.deewr.gov.au/Schooling/QualityTeaching/Pages/Qualityteaching.as px

Endler, L. C. \& Bond, T. G. (2008). Changing science outcomes: Cognitive acceleration in a US setting. Research in Science Education, 38, 149-166.

Endler, L. C., \& Bond, T. G. (2001). Cognitive development in a secondary science setting. Research in Science Education, 30(4), 403-416.

Eppig, C., Fincher, C. L., \& Thornhill, R. (2010). Parasite prevalence and the worldwide distribution of cognitive ability. Proceedings of the Royal Society, 77(1701), 3801-8.

Fullarton, S., Walker, M., Ainley, J., \& Hillman, K. (2003). Patterns of participation in Year 12. Longitudinal Surveys of Australian Youth Research Report 33. Camberwell, Victoria: Australian Council for Educational Research. Accessed 20 March 2011 at http://www.acer.edu.au/lsay

General Teaching Council for England. (2001). Improved learning through cognitive intervention. Accessed July 1, 2008 at: http://www.gtce.org.uk/research/romtopics/rom_teachingandlearning/case_jun0 1/study

Hackman, D. A., Farah, M. J., \& Meaney, M. J. (2010). Socioeconomic status and the brain: Mechanistic insights from human and animal research. Nature Reviews Neuroscience, 11(9), 651-659.

Hattie J. (2009) Visible learning: A synthesis of over 800 meta-analyses relating to achievement. London: Routledge.

Hautamäki, J., Kuusela, J., \& Wikström, J. (2002, July). CASE and CAME in Finland: "the second wave." Paper presented at the $10^{\text {th }}$ International Conference on Thinking, Harrogate, UK.

Higgins, S., Baumfield, V., Hall, E. (2007) Learning skills and the development of learning capabilities. In: Research Evidence in Education Library. London: EPPI-Centre, Social Science Research Unit, Institute of Education, University of London. Accessed March 202011 at: http://eppi.ioe.ac.uk/cms/Default.aspx?tabid=1851

Inhelder, B. \& Piaget, J. (1958). The growth of logical thinking from childhood to adolescence. London: Routledge \& Kegan Paul.

Iqbal, H. M. \& Shayer, M. (2000). Accelerating the development of formal thinking in Pakistan secondary school students: Achievement effects and professional development issues. Journal of Research in Science Teaching, 37(3), 259-274.

Larkin, S. (2002). Creating metacognitive experiences for 5- and 6-year-old children. In M. Shayer \& P. Adey (Eds.), Learning intelligence: Cognitive acceleration across the curriculum from 5 to 15 years (pp. 65-79). Buckingham, UK: Open University Press.

Lin, C., Hu. W., Adey, P., \& Shen, J. (2003). The influence of CASE on scientific creativity. Research in Science Education, 33, 143-162. 
Mbano, N. (2003). The effects of a cognitive acceleration intervention programme on the performance of secondary school pupils in Malawi. International Journal of Science Education, 25(1), 71-87.

McGuinness, C. (1999). From thinking skills to thinking classrooms: A review and evaluation of approaches for developing pupils' thinking. Research Report No. 115. Norwich, UK: Department for Education and Employment.

Moll, L. C. (Ed.). (1990). Vygotsky and education: Instructional implications and applications of sociohistorical psychology. Cambridge, UK: Cambridge University Press.

Organisation for Economic Co-operation and Development (OECD). (2010). The high cost of low educational performance. OECD Publishing.

The Office for Standards in Education, Children's Services and Skills (Ofsted). (2008). Success in science. London, UK: Author. Reference No. 070195. Accessed 20 March 2011 at: www.ofsted.gov.uk

Shayer, M., Adey, P. S., \& Wylam, H., (1981). Group tests of cognitive developmentideals and a realization. Journal of Research in Science Teaching, 18, 157-168.

Shayer, M., Küchemann, D. E., Wylam, H. (1976). The distribution of Piagetian stages of thinking in British middle and secondary school children. British Journal of Educational Psychology, 46, 164-173.

Shayer, M. (2003). Not just Piaget, not just Vygotsky, and certainly not Vygotsky as an alternative to Piaget. Learning and Instruction, 13, 465-485.

Shayer, M. (1999). Cognitive acceleration through science education II: Its effects and scope. International Journal of Science Education, 21(8), 883-902.

Shayer, M. \& Adey, P. (2002). Learning intelligence: Cognitive acceleration across the curriculum from 5 to 15 Years. Buckingham, Open University Press.

Shayer, M., \& Adhami, M. (2010). Realizing the cognitive potential of children 5-7 with a mathematics focus: Post-test and long-term effects of a 2-year intervention. British Journal of Educational Psychology, 80(3), 363-379.

Shayer, M., \& Ginsburg, D. (2009). Thirty years on - a large anti-Flynn effect? (II): 13- and 14-year-olds. Piagetian tests of formal operations norms 1976-2006/7. British Journal of Educational Psychology, 79, 409-418.

Shymansky, J., Wang, T.-L., Annetta, L., Yore, L., \& Everett, S. (in press). How Much Professional Development is Needed to Effect Positive Gains in K-6 Student Achievement On High Stakes Science Tests? International Journal of Science and Mathematics Education, available online

Smith, M. K., Wood, W. B., Adams, W. K., Wieman, C., Knight, J. K., Guild, N., \& $\mathrm{Su}, \mathrm{T}$. , (2009). Why peer discussion improves student performance on in-class concept questions. Science, 323(5910), 122-124.

Stephenson, J. (2009). Best practice? Advice provided to teachers about the use of Brain Gym® in Australian schools. The Australian Journal of Education, 53(2), 109-124.

Tashakkori, A. \& Teddlie, C. (2008). Quality of inferences in mixed methods research: Calling for an integrative framework. In M. M. Bergman (Ed.), Advances in mixed methods research (pp. 101-119). London: Sage.

Taylor, J., Roehrig, A. D., Hensler, B. S., Connor, C. M., \& Schatschneider, C. (2010). Teacher quality moderates the genetic effects on early reading. Science, 328(5977), 512-514.

Thomson, S. \& de Bortoli, L. (2008). Exploring scientific literacy: How Australia measures up. The PISA 2006 survey of students' scientific, reading and 
mathematical literacy skills. Camberwell, Victoria: ACER Press. Accessed 29 March 2011 at: http://www.acer.edu.au

Thomson, S., Wernert, N., Underwood, C., Nicholas, M. (2008). TIMMS 07: Taking a closer look at mathematics and science in Australia. Melbourne: Australian Council for Educational Research ACER (2008). Accessed 20 March 2011 at: www.acer.edu.au/timss07/

Thomson, S., De Bortoli, L., Nicholas, M., Hillman, K., \& Buckley, S. (2011). Challenges for Australian education: Results from PISA 2009: the PISA 2009 assessment of students' reading, mathematical and scientific literacy. Melbourne: Australian Council for Educational Research.

Tucker-Drob, E. M., Rhemtulla, M., Harden, K. P., Turkheimer, E., \& Fask, D. (2011). Emergence of a Gene X Socioeconomic Status Interaction on Infant Mental Ability between 10 months and 2 years. Psychological Science, 22(1), 125-133.

Turkheimer, E., Haley, A., Waldron, M., D'Onofrio, B., \& Gottesman, I. I. (2003). Socioeconomic status modifies heritability of IQ in young children. Psychological Science, 14(6), 623-628.

Tytler, R. (2007). Re-imagining science education: Engaging students in science for Australia's future. Camberwell, Victoria: Australian Council for Educational Research Press. Accessed 20 March 2011 at: www.acer.edu.au

Venville, G., Adey, P. Larkin, S., \& Robertson, A. (2003). Fostering thinking through science in the early years of schooling. International Journal of Science Education, 25(11), 1313-1331.

Yin, R. (2003). Case study research: Design and methods ( $3^{\text {rd }}$ ed.). Thousand Oaks, CA: Sage. 
Figure 1

The Professional Development Program over Two Years
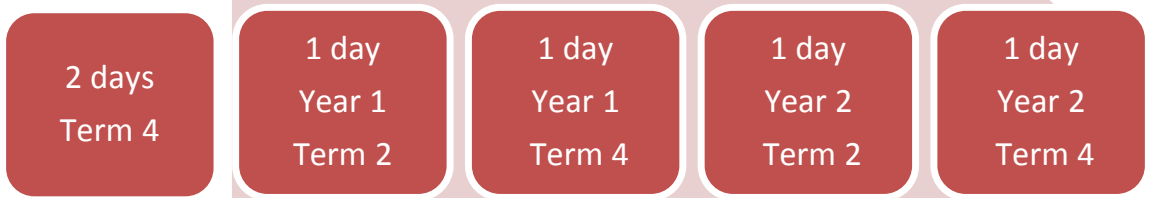
Table 1

Pre/Post Intervention Cognitive Gains as Measured by Science Reasoning Tasks

\begin{tabular}{|c|c|c|c|c|c|}
\hline & $\mathbf{n}$ & $\begin{array}{l}\text { Pre-test } \\
\text { mean (SD) }\end{array}$ & $\begin{array}{l}\text { Post-test } \\
\text { mean (SD) }\end{array}$ & Gain & Effect size \\
\hline Case study school & 68 & $4.82(0.94)$ & $5.75(0.77)$ & $0.94(0.95)$ & 0.47 \\
\hline $\begin{array}{l}\text { Comparison } \\
\text { control }\end{array}$ & 120 & $6.17(1.03)$ & $6.64(1.36)$ & $0.46(1.09)$ & \\
\hline
\end{tabular}


Table 2

Pre/Post Intervention Cognitive Gains as Measured by Science Reasoning Tasks

\begin{tabular}{llll}
\hline & n & Mean Gain (SD) & Effect size \\
\hline Males case study school & 37 & $1.02(0.84)$ & 0.81 \\
Specialist all male class & 15 & $1.16(0.97)$ & 0.90 \\
Males in mainstream classes & 22 & $0.93(0.74)$ & 0.75 \\
Males comparison control & 63 & $0.27(1.01)$ & \\
Females Case study school & 31 & $0.84(1.08)$ & 0.15 \\
Females comparison control & 57 & $0.67(1.13)$ & \\
\hline
\end{tabular}


Table 3

Gains from Year 7 to Year 9 on State-wide and National Tests in Science, Reading, Spelling and Numeracy

\begin{tabular}{llccccc}
\hline Group & Measure & n & Science & Reading & Spelling & Numeracy \\
\hline Mean & & & & & \\
& gain & 68 & 48.4 & 39.8 & 38.0 & 41.0 \\
& SD & & 40.9 & 41.3 & 32.1 & 32.4 \\
& Effect & & & & & \\
& size & & 0.21 & 0.06 & -0.08 & -0.04 \\
& & & & & & \\
All other state schools school & gain & 12,000 & 39.3 & 37.2 & 41.3 & 42.7 \\
& SD & & 46.8 & 46.3 & 42.2 & 42 \\
& & & & & \\
& Mean & & & & & \\
Specialist all male class & gain & 14 & 73.4 & 13.3 & 36.9 & 50.3 \\
& SD & & 40.5 & 36.5 & 18.3 & 29.9 \\
& Effect & & & & & \\
& size & & 0.78 & -0.68 & -0.14 & 0.21 \\
\hline
\end{tabular}


Table 4

Students' Responses to a Qualitative Survey about the Cognitive Acceleration Program $(n=106)$

\begin{tabular}{lccc}
\hline Question & $\begin{array}{c}\text { Positive } \\
\text { response }\end{array}$ & $\begin{array}{c}\text { Neutral } \\
\text { response }\end{array}$ & $\begin{array}{c}\text { Negative } \\
\text { response }\end{array}$ \\
\hline $\begin{array}{l}\text { Did you enjoy the thinking lessons? } \\
\text { How did you feel at the end of the }\end{array}$ & 72 & 13 & 15 \\
$\begin{array}{l}\text { thinking lessons? } \\
\text { Would you like to do more of the }\end{array}$ & 77 & 10 & 4 \\
thinking lessons? & & & \\
Do you feel the thinking lessons & 88 & 10 & 2 \\
have helped you? & & & \\
\end{tabular}

